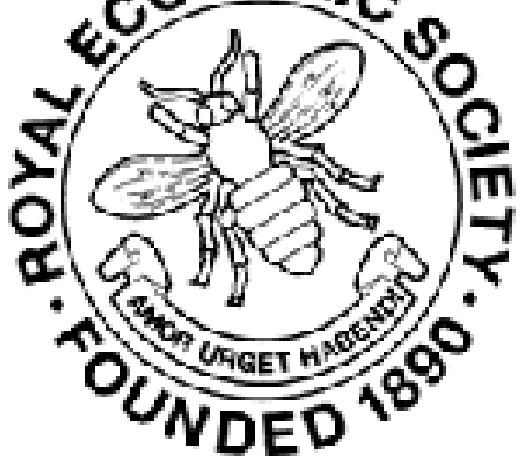

\title{
WILEY
}

\section{The Indian Currency Committee's Report}

Author(s): F. C. H.

Source: The Economic Journal, Vol. 3, No. 11 (Sep., 1893), pp. 511-515

Published by: Wiley on behalf of the Royal Economic Society

Stable URL: http://www.jstor.org/stable/2955715

Accessed: 25-06-2016 22:29 UTC

Your use of the JSTOR archive indicates your acceptance of the Terms \& Conditions of Use, available at

http://about.jstor.org/terms

JSTOR is a not-for-profit service that helps scholars, researchers, and students discover, use, and build upon a wide range of content in a trusted digital archive. We use information technology and tools to increase productivity and facilitate new forms of scholarship. For more information about JSTOR, please contact support@jstor.org.

Royal Economic Society, Wiley are collaborating with JSTOR to digitize, preserve and extend access to The Economic Journal 
ments bear any loss caused by their face value falling in terms of gold.

MM. Montefiore Levi and Sainctelette favoured a plan under which no one could bring the one metal to the mints without a fixed proportion of the other.

Of these proposals three are of commanding interest-M. de Rothschild's on account of the support it received, M. Allard's on account of the idea of distributing the loss upon silver notes upon the issuer, and M. Levi's because of its novel and scientific character. So far as I am aware, to these two gentlemen (MM. Levi and Sainctelette), after Prof. Marshall, who had proposed a similar system, belongs the merit of suggesting a method for keeping gold and silver stable by affecting not merely the conditions of demand but also of supply.

It is interesting to compare the attitude of the different countries. France, carrying with her in the main the other countries of the Latin Union, gave through M. Tirard a most able expression of her view that other states before calling upon her for assistance should bring up their per capita quantity of silver money to something approaching the fifty francs a head used by her. At the same time she concurred that a greater stability in the rates was desirable. Germany, through Count Alvensleben, agreed with the view expressed in this last sentence, but was satisfied with her own position whilst stating that any proposed remedies would receive the most careful examination by the Imperial Government. Austria, Count Khevonshüller Metsch averred, was animated with a sincere desire for a tangible result and though passing through a stage of currency transition would scrupulously consider any proposals. Turkey hoped for an international agreement, whilst Russia commented upon the obstructive attitude of England. The Netherlands, Spain and America advocated bimetallism, but the delegates of the latter country explained that they could not speak with plenary authority owing to the approaching change in their government. India was in favour of bimetallism, but failing that was prepared to consider palliatives.

There was a general consensus of opinion (pace Mr. Currie and M. Weber) that gold was dangerously appreciating in terms of commodities. A majority apparently considered bimetallism (without England's active co-operation) impracticable, but hoped that ultimately measures for the further employment of silver might be internationally agreed upon.

F. C. HARRISON

\section{The Indian Currency Committee's Report.}

Silver, in the view of the Committee, has been falling, is falling, and will fall further in its gold price if, as is not improbable, the Sherman Act be repealed. This being so, the finances of the Indian Government cannot be maintained in equilibrium by the ordinary 
expansion of the revenue, whilst a further additional burden will have to be thrown upon them to compensate officials paid by fixed silver salaries. The Committee proceed to show that a fluctuating exchange hinders trade and checks investment, whilst a falling exchange causes the burden of taxation to vary in respect of different classes of the population. After this temperate description of India's difficulties, the question of the remedy is next discussed. Increased taxation naturally suggests itself. The land revenue, however, it is urged, cannot be touched, for one quarter of it is permanently settled, whilst the rest is fixed upon thirty years' assessments. Stamp duties tax justice. Import duties would incense suffering Lancashire, and a countervailing excise would be difficult of enforcement. Export duties are unsound. An increase of the income-tax would be unpopular and hit those classes who are most injured by the fall in exchange. Taxes on tobacco and sugar would be difficult to collect, and would realise a small net return, whilst it is prudent to retain an increase in the salt duty as a war reserve. Having thus arrived at the conclusion that increased taxation is impracticable, the Committee is driven to consider the proposals of the Indian Government. These are (1) to close the mints to free coinage of silver, and to open them to gold at a rate fixed with reference to the average exchange of the years immediately previous ; (2) to reduce the rupee circulation in the event of the value of the rupee not rising to the declared par ; (3) to coin about ten millions of rupees a year on equilibrium being attained; (4) to give gold in exchange for silver when possible.

The Committee point out that as India takes one quarter and America one third of the annual production of silver, the result would be a fall in the gold price of silver, to be followed by a further fall if America followed India's example. It further observes that the fall cannot be measured, and that before the value of the rupee can diverge from its bullion value, the unused hoarded rupees in India would have to be reckoned with. A digression follows, adducing the experience of other countries, who under diverse conditions have succeeded in maintaining the ratio to gold of a large quantity of circulating silver or notes. A return is then made for the purpose of examining the five main objections taken to India's proposals--namely,

(a) That gold is unsuited to India.

(b) That the currency will not be regulated automatically.

(c) That the burden of taxation will be materially affected.

(d) That peasants' savings will be depreciated.

(e) That the balance of trade turning against India, the rupee will not maintain its enhanced value.

The first objection is easily disposed of. Gold was in use as currency up to 1835 . The people liked it, and they continue to import it. In answering $(b)$ it is shown that an automatic upper limit is imposed 
by admitting gold to the mints at the rate of $1 s .4 d$., and that the undesirable regulation of the silver coinage can be obviated by giving the tenderer of gold the right to demand silver at the legal ratio. In regard to $(c)$ it is said that the adoption of a low rate would cause a very slight change, and the resultant loss would fall on those who had previously gained at the expense of the rest of the country. Respecting $(d)$ it is admitted that uncoined silver and ornaments will become depreciated, but the latter, in the opinion of the Committee, are rarely used as a realisable security.

The last objection $(e)$ is discussed at greater length. The Committee are not, however, so happy in their broad statement (par. 22) of the effect upon trade of a falling exchange, as when they deal in the latter part of the report with the two main contentions of the supporters of the stimulus theory, i.e., that India's trade with China will suffer, and that China will undersell India in the markets of the West. To those who say that China will only give the same silver (which will be worth fewer rupees) for Indian cotton and Indian opium it is answered, admitting for the moment that the manufacturer finds a difficulty in diminishing the rupee cost of production, that Indian produce is paid for three-corner-wise by China's exports to other countries, and that the gold price of those exports does not necessarily fall with the gold value of silver ; in other words that China, getting a higher silver price, can afford to give India a better silver price, i.e., the same number of rupees for her commodities. It is further said that Indian opium is a luxury which China will buy at any price.

Regarding China's competition with India in gold markets, it is first contended, in limine, that China cannot compete, owing to deficient railway communication, heavy imposts, and want of enterprise; secondly, that with regard to tea, China cannot produce Indian tea; and lastly, that the cost of production (wages, etc.) will adjust itself to the fall in silver, and that a study of the Indian export trade affords no countenance to the theory that during the process of adjustment the advantage to the Chinese producer will be considerable.

After disposing of these five main objections to the proposals of the Indian Government, the Committee dismiss alternative suggestions as being inferior, stating incidentally that the idea of a sliding seignorage presents practical difficulties, and is in reality an indirect method of arriving at the same goal. The report concludes with a unanimous recommendation in favour of the Indian proposals as modified by the Committee : two members, however, recommend the accumulation of a gold reserve, whilst Mr. Currie would leave the market to settle the ratio and Mr. Courtney has hankerings after the scheme for a sliding seignorage.

There are several noticeable features about this very able report, but undoubtedly the most noticeable is the attempt to judge what is possible in India by a comparative study of monetary principles in their 
actual working in the currency systems of other countries. The next point which strikes a critic, is that it is unfortunate in the extreme that the financial position of the Indian Government rendered it necessary in the opinion of that government and the Committee to introduce the question of taxation by currency into proposals for currency reform.

While admitting to some extent, the force of the allegations that Indian tea is different to China tea, that China will continue to pay the same price for India's opium, and that China is a country likely to be backward in commercial competition, many will probably agree with Mr. Hermann Schmidt, that the government may lose by a decrease in the opium and railway revenue what it gains by an improved exchange, and that the balance of trade may disappear owing to the causes already alluded to and the stimulus given to English exports by a rising exchange.

There can be little question, whatever the permanent effect may be, that a great divergence between the value of the rupee and silver must dislocate trade. In view, therefore, of possible failure, and impending changes in America, the wiser course would have been to rate silver at the price of the day, and to meet the deficit by additional taxation, ${ }^{1}$ or, in the last resort, by a loan. As it is, confidence has been shaken by the action of the Indian Council in accepting tenders at a lower rate than the declared par of $1 s .4 d$., and a loan, after all, may be required to secure success.

A point which has been much debated is the question of the gold that India will use monetarily. Sir David Barbour is probably correct in holding that there are no solid grounds for supposing that those who in India hoard gold or distribute it upon the persons of their women-kind will bring much of it to the mints. As, however, he proposes to offer the bait of no seignorage, it may well be that on importation gold will first pass through the mints and that some will convert their hoards of ingots, sovereigns, or mohurs into current coin, which in times of distress or in the export season may occasionally reappear in the circulation. On the other hand, of the 180 millions sterling of gold which is in India, whatever is in the form of mohurs is generally worth more than its bullion value, and the rest is nearly all in the form of ornaments. During the export season it is not improbable that the rupee will rise to a fraction over the legal par and gold will enter the country. For it and any other gold reaching the government treasuries a place can be found in the currency reserves, and it can be paid out at a small premium to those requiring it for export.

1 Something could probably be realised by a tax on cigars. Bengal is under the permanent settlement, and contributes too little to the Imperial exchequer. To break the settlement openly would provoke much comment and excite political discontent, but it might not be impracticable to impose a succession duty, or a land cess, the proceeds of which could be given to the local government, an equivalent amount being withdrawn from the Imperial contribution. 
Other points of interest arise in connection with rupees existing outside India, silver hoards, and ornaments. Undoubtedly rupees existing beyond the Indian frontier and across the seas will return on their acquiring a monopoly value. The quantity, however, that could so return is small. Existing hoards of rupees, which may be estimated at fifty crores, are not likely to be affected. Those who believe in the success of the present experiment will withhold them until their value rises to $1 s .4 \bar{d}$., and when it does so rise, there is no reason for parting with them except a disbelief in the stability of the ratio attained.

The effect of the present experiment upon uncoined silver and ornaments has been much exaggerated. Two facts may be pointed out in this connection: (1) that there is little uncoined silver in India, the entire import, with insignificant exceptions, passing into the British and native mints; and (2) that ornaments are not brought in any quantities to the Indian mints. For the last twenty years the percentage of country silver and ornaments brought to the mints is not four per cent. of their total receipts. The greatest amount brought into the Calcutta Mint for the last twenty years is six and a half lakhs, whilst exclusive of 1877 to 1880 , the largest quantity brought into the Bombay Mint for sixty years is twenty-eight lakhs. During the three years named the quantity of such silver so brought was $3 \cdot 3$ crores, and not 4.5 crores as is erroneously stated by the Committee, who have included in their figures a quantity of native coin. With this notable exception, the quantity brought during recent famines has been inappreciable. It may also be noted that with the present extended railway communication famines are less likely to recur. Sir David Barbour has moreover drawn attention to the fact that as bullion falls in value the peasant who likes silver ornaments will get them cheaper.

F. C. H.

\section{The Rate Fixed by the Indian Government for Council BiLls.}

The rate fixed by the Indian Government for the selling price of Council Bills in London has been the subject of some discussion. It was resolved to place this at $1 s .4 d$. for the rupee, which is equivalent to fifteen rupees for the pound sterling.

The question has been asked, why did not the Indian Government fix the rate at a higher level-for instance, at $2 s$. for the rupee? From the point of view of the finances of the Indian Government this would obviously have been preferable, and if the one level-that at $1 \mathrm{~s} .4 \mathrm{~d}$.-is attainable, it is not immediately obvious why the other-at 2s.-might not be available also.

Both are equally artificial rates. The Indian 'Government has sought by its action to separate the price of bills from the price of silver; if its power over the market for bills is sufficient to maintain 